\title{
Improvement of Wax Oil Content of Embryonic Callus of Jojoba Using Gamma Radiation
}

\section{Hattem M. El-Shabrawi, Hend E. Wahba ${ }^{1}$, Ahmed M Gabr, Shafik I. El- Morsy $^{2}$ Mohamed A. Saber ${ }^{2}$ and Shawky A. Bekheet*}

Plant Biotechnology Department, National Research Centre (NRC), 12622 -El-Buhouth St., Dokki, Cairo, Egypt

Key words: Wax oil content, Embryonic callus, Jojoba, Gamma radiation

\begin{abstract}
Embryogenic callus was obtained from the leaf explants of jojoba (Simmondsia chinensis (Link) Schneider cultured on MS containing $0.5 \mathrm{mg} / \mathrm{NAA}$ and $0.5 \mathrm{mg} / \mathrm{Kn}$. Growth of embryonic callus increased in $0.5 \mathrm{mg} / \mathrm{Kn}+6 \%$ sucrose. In order to improve oil content, the embryonic callus was exposed to different doses $(5,10$ and $15 \mathrm{Kr}$ ) of gamma radiation. It was found that oil content of embryonic callus of jojoba increased $1.41 \%$ by exposing to $5 \mathrm{Kr}$ gamma radiation. Also, size of oil bodies in embryonic callus irradiated with $5 \mathrm{Kr}$ increased compared to control. Furthermore, production of the fatty acids was enhanced by gamma irradiation. The highest percentage of total fixed oil (1.41) was recorded in $5 \mathrm{Kr}$ radiation. However, the highest content of total fatty acids (98.612) was obtained when embryonic callus were exposed to $10 \mathrm{Kr}$ of gamma radiation.
\end{abstract}

\section{Introduction}

Simmondsia chinensis (Link) Schneider, commonly known as jojoba is the sole species of Simmondsiaceae and is native to the Sonora desert of south-western USA and northern Mexico (Mills et al. 1997). The seeds of jojoba contain a light-gold-colored wax ester (jojoba oil) that makes $50-55 \%$ of the seed weight. The oil contains the same properties as the oil obtained from the sperm only traces of saturated wax, steroids and tocopherol (Low and Hackett 1981). The liquid wax and its derivatives are potent in a wide range of applications in cosmetics (lipsticks, face creams, skin fresheners, winter care lotions, shampoos, moisturizers, soaps), lubricants, anti-foaming agents, electrical insulators, and plastic industries (Reddy and Chikara 2010). Because of all the above characteristics, jojoba oil is claimed to be one of nature's gifts to human race or liquid gold from the

*Author for correspondence: <shawky005@yahoo.com>. ${ }^{1}$ Medecinal and Aromatic Plant Department, National Research Centre (NRC), 12622-El-Buhouth St., Dokki, Cairo, Egypt. ${ }^{2}$ Department of Botany, Faculty of Agriculture, Al-Azhar University, Cairo, 11884, Egypt.

DOI: https://doi.org/10.3329/ptcb.v29i2.44509 
desert (Bhardwaj et al. 2010). Moreover, the plant can be easily cultivated on marginal land that are not used for conventional agricultural crops and thus does not put pressure on fertile agricultural land. Jojoba is dioecious plant and female individuals are generally considered to be more valuable as they produce fruit and seeds. The advantage of using asexual propagules in commercial jojoba plantations is that these supply an equal and predictable plant growth and yield (Birnbaum et al. 1984, Lee 1988). Clonal propagation of elite individuals of known sexuality is thus necessary to ensure that commercial plantations will be productive (Chaturvedi and Sharma1989).

Although vegetative propagation of jojoba can be made by rooting semi-hard wood cuttings (Lee1988), this approach yields only a limited number of propagules. Plant cell and tissue culture techniques have immense potential for the improvement of jojoba regeneration and multiplication. Moreover, somatic embryogenesis is useful for genetic transformation (Kim and Liu 1999) and to improve product of jojoba oil (Benzioni 1995). Only a few reports on somatic embryogenesis in jojoba are available, and most of them involve in vitro wax production from immature zygotic embryos (Lee and Thomas 1985, Wang and Janick 1986a,b). In this respect, Hamama et al. (2001) developed a protocol for the induction, maturation and germination of somatic embryos from leaf tissue of jojoba. Otherwise, in vitro production of oil (largely liquid wax) has been demonstrated in newly induced callus tissues from cotyledons (Rost and Paterson 1978).

Gamma-rays are a powerful tool of ionizing radiation for mutations. It can hold several hundred energy levels and the most penetrating radiation source comparing to alpha and beta rays (Kovács and Keresztes 2002). Gamma-rays can damage or modify important molecules in plant cells which should make diverse changes at different levels morphologically and biochemistry based on the irradiation power. In this regard, some workers have investigated the effects of gamma radiation on plants, including changes at the morphological, physiological and biochemical levels. These effects include changes in the plant photosynthetic pigments, composition of chemical, cellular structure and crude oil yield (Wi et al. 2005). The present work aimed at improving the jojoba oil content using mutated embryonic cultures irradiated with gamma radiation.

\section{Materials and Methods}

Leaves of jojoba were collected from plants cultivated in Faculty of Agriculture farm, Azher University in Cairo, Egypt. Leaf pieces were used as explants.

Mature leaves were surface sterilized under air laminar Flow Cabinet by soaking in $70 \%$ alcohol for $1 \mathrm{~min}$ and then immersed in $10 \%(\mathrm{v} / \mathrm{N})$ commercial bleach for $30 \mathrm{sec}$ following by rinsing five times in sterile distilled water. For culturing, leaves were cut into $1 \mathrm{~cm}$ pices.

For callus induction, leaf explants were cultured on MS supplemented with different combinations of 2,4-D, BAP, NAA and Kn. Callus obtained from best combination (0.5 $\mathrm{mg} / \mathrm{NAA}$ and $0.5 \mathrm{mg} / \mathrm{Kn}$ ) was maintained in dark condition on growth medium for 28 
days in culture room at $25^{\circ} \mathrm{C}$. The selected callus were used for the next subcultures. Continuous subcultures were carried out in the same conditions of three subcultures at 4 weeks interval. For embryonic cultures, the calluses were sub-cultured on MS supplemented with 0.1 and $0.5 \mathrm{mg} /$ of $\mathrm{Kn}$ in combination with two levels (4 and $6 \%$ ) of sucrose and incubated on $16 \mathrm{hrs}$ photoperiod provided by white fluorescent tubes (3000 lux light intensity). All media were solidified with $2 \mathrm{~g} /$ gelrite and the $\mathrm{pH}$ was adjusted to 5.8 before autoclaving at $121^{\circ} \mathrm{C}$ for $15 \mathrm{~min}$.

The experiments were set up as a separate completely randomized design and data were statistically analyzed using standard error (SE) according to the method described by Snedecor and Cochran (1980).

The embryonic cultures were exposed to three doses i.e., 5, 10 and $15 \mathrm{Kr}$ of gammarays. The radiation source of the experiment was Cobalt-60 gamma, $1 \mathrm{Kr}=10$ gray (Gy). The half-life of $1 \mathrm{Kr}$ Co-60 was 28.22 in May, 2013. This part of study was carried out in Egyptian Atomic Energy Authority (EAEA), Nasr city.

Selected samples of cultures without radiation (T1), cultures exposed to 5 (T2), 10 (T3) and $15 \mathrm{Kr}$ (T4) were fixed for $2 \mathrm{hrs}$ in $2 \%(\mathrm{w} / \mathrm{N})$ paraformaldehyde and $2.5 \%(\mathrm{v} / \mathrm{N})$ glutaraldehyde in phosphate buffer $0.1 \mathrm{M}, \mathrm{pH}$ 7.4. After fixation, the embryonic cultures were washed with phosphate buffer $0.1 \mathrm{M}, \mathrm{pH} 7.4$, for $10 \mathrm{~min}$, re-suspended in $1 \%(\mathrm{w} / \mathrm{N})$ paraformaldehyde for $2 \mathrm{hrs}$ and then rinsed three times with phosphate buffer. Embryonic cultures were post fixed for $2 \mathrm{hrs}$ with $1 \%(\mathrm{w} / \mathrm{N})$ osmiumtetroxide containing $0.8 \%(\mathrm{w} / \mathrm{v})$ potassium hexacyanoferrate prepared in phosphate buffer, followed by four washes with deionized water and sequential dehydration in acetone. All procedures were performed at $4^{\circ} \mathrm{C}$. Samples were embedded in Spurr's Resin and polymerized at $60^{\circ} \mathrm{C}$ for $48 \mathrm{hrs}$. Ultrathin sections $(70 \mathrm{~nm})$ were obtained with a diamond knife $\left(45^{\circ}\right.$, Diatome). Sections were stained with uranyl acetate and Reynolds lead citrate for $10 \mathrm{~min}$ and examined with a JEOL 1400 transmission electron microscope equipped with a GatanUltrascanES1000 CCD Camera. Three inocoula of embryonic cultures were used in each analysis. Grids were stained with uranylacetate and Reynolds lead citrate solutions. The samples were viewed on a JEM-1400 transmission electron microscope (JEOL, Japan).

The fixed oil percentage of the embryonic cultures for each treatment was determined according to A.O.C.S. (1995). Five grams of powdered tissues for each sample were extracted with petroleum ether $\left(40-60^{\circ} \mathrm{C}\right)$ in a continuous extraction apparatus. The extract was evaporated under reduced pressure at $40^{\circ} \mathrm{C}$ leaving the desired oil product, and then the oil was weighed.

$$
\text { Percentage of total lipids }=\frac{\text { Weight of lipids residue }}{\text { Weight of dry sample }} \times 100
$$

Methyl esters of fatty acids were prepared by refluxing $10 \mathrm{mg}$ of the liberated fatty acids with $10 \mathrm{ml}(2 \%)$ of $\mathrm{H}_{2} \mathrm{SO}_{4}$ in anhydrous methanol for $5 \mathrm{hrs}$ on a water bath at $90^{\circ} \mathrm{C}$. 
The fatty acid methyl esters were extracted with petroleum ether $(10 \mathrm{ml}$ each). The petroleum ether extract was treated with diluted sodium bicarbonate solution to remove the acidity, washed several times with distilled water, dried over anhydrous sodium sulphate, filtered and concentrated under reduced pressure (Maestri and Guzman 1995). The product was analyzed by gas chromatography (GC) technique for separation and identification of the fatty acids. These analyses were carried out in the Central Services Laboratory, National Research Centre, Cairo, Egypt. The qualitative identification of the fatty acid was achieved by comparing the retention time $\left(R_{t}\right)$ of their peaks with those of the expected authentic chromatographed under the same conditions. The percentage as well as their $R_{t}$ was computed and presented on the chromatograms.

Column, Hewlett Packard 6890A HP gas chromatograph with column: capillary column HP5,5\% phenyl methyle-siloxan. Lenth $30 \mathrm{~m}$, diameter $320 \mu \mathrm{m}$ jim thickness, 0.25 $\mu \mathrm{m}$. Temperature program: rate $4^{\circ} \mathrm{C} / \mathrm{min}$, final temp $220^{\circ} \mathrm{C}$, final time, 60 min Gasses flow rates: $\mathrm{N} 230 \mathrm{ml} \mathrm{min}, \mathrm{H} 220 \mathrm{ml} \mathrm{m}$, air $20 \mathrm{ml}$ min injetian temperature: $250^{\circ} \mathrm{C}$, detector temperature $280^{\circ} \mathrm{C}$ (flame ionization detector).

\section{Results and Discussion}

Six different combinations of 2,4-D, BA, NAA and Kn were applied to investigate callus induction from leaf explants of jojoba. Data of Table 1 indicate that all the combinations showed callogenic response of leaf explants. Callus initiation started from the cut surface of the leaves which were in touch with the medium within four weeks of culturing. The results showed that medium containing $0.5 \mathrm{mg} / \mathrm{NAA}$ and $0.5 \mathrm{mg} / \mathrm{Kn}$ gave highest fresh weight $(2.20 \mathrm{~g})$ of creamy green callus. While, the medium containing $0.5 \mathrm{mg} /$ NAA and $0.5 \mathrm{mg} / \mathrm{BAP}$ did not produce $(0.0)$ any callus. The calli formed from leaf explants were periodically subcultured after 4 weeks for multiplication and maintenance on medium contained same combinations of cytokinins and auxins. The results of Table 2 revealed that medium containing $0.5 \mathrm{mg} / \mathrm{NAA}$ and $0.5 \mathrm{mg} / \mathrm{Kn}$ increased the fresh

Table 1. Callus induction of jojoba from leaf explants on different combinations of BA, Kn, NAA and 2,4-D.

\begin{tabular}{lcllc}
\hline Treatment & $\begin{array}{c}\text { Callus } \\
\text { frequency }\end{array}$ & Color & $\begin{array}{l}\text { Callus fresh } \\
\text { weight }(\mathrm{g})\end{array}$ & Texture \\
\hline $0.5 \mathrm{mg} / \mathrm{BAP}+0.5 \mathrm{mg} / \mathrm{NAA}$ & - & - & - & - \\
$0.5 \mathrm{mg} / \mathrm{BAP}+1 \mathrm{mg} / \mathrm{NAA}$ & + & Creamy & $1.7 \pm 0.02$ & Friable \\
$0.5 \mathrm{mg} / \mathrm{BAP}+0.5 \mathrm{mg} / \mathrm{l} 2,4-\mathrm{D}$ & ++ & $"$ & $1.3 \pm 0.11$ & $"$ \\
$0.5 \mathrm{mg} / \mathrm{BAP}+1 \mathrm{mg} / \mathrm{l}$ 2,4-D & + & $"$ & $1.9 \pm 0.20$ & $"$ \\
$0.5 \mathrm{mg} / \mathrm{Kn}+0.5 \mathrm{mg} / \mathrm{NAA}$ & ++ & Creamy green & $2.2 \pm 0.41$ & Compact \\
$0.5 \mathrm{mg} / \mathrm{Kn}+1 \mathrm{mg} / \mathrm{NAA}$ & ++ & Creamy & $1.8 \pm 0.05$ & Friable \\
\hline
\end{tabular}

\pm Standard Error (SE). 
weight of callus (5.8 g) and callus behavior on this medium was compact in all subculture periods. However, callus was friable with other combinations of growth regulators. These data are in agreement with those reported by (Hamama et al. 2001, El-Ashry et al. 2017). However, Kumar et al. (2013) reported higher frequency of callus proliferation from leaf explants of field grown jojoba mature plants and cultured on MS supplemented with 2,4-D (2 mg $\Lambda)$ and BA $(0.5 \mathrm{mg} \Lambda)$ within 20 - 22 days of inoculation. Sardana and Batra (1998) produced callus from leaf explants of jojoba on MS with $1.0 \mathrm{mg} / \mathrm{NAA}$ and 3.0 or $5.0 \mathrm{mg} /$ BAP. High percentage of callus induction (98.7) was obtained by Bala et al. (2015) by culturing of leaf explants on 2, 4-D ( $1 \mathrm{mg} \Lambda)$ and BAP $(0.5 \mathrm{mg} \Lambda)$ containing medium. Recently, Ibrahim et al. (2018) mentioned that the use of the combination of dicamba $(1.5 \mathrm{mg} \Lambda)$ and TDZ $(0.75 \mathrm{mg} \Lambda)$ produced the highest percentage of callus from leaf explants of jojoba.

Table 2. Callus growth of jojoba after third subculture at different combinations of BA, Kn, NAA and 2,4-D.

\begin{tabular}{|c|c|c|c|c|}
\hline Treatment & $\begin{array}{c}\text { Callus } \\
\text { frequency }\end{array}$ & Color & $\begin{array}{c}\text { Callus fresh } \\
\text { weight }(\mathrm{g})\end{array}$ & Texture \\
\hline $0.5 \mathrm{mg} / \mathrm{BAP}+0.5 \mathrm{mg} \Lambda \mathrm{NAA}$ & - & - & - & - \\
\hline $0.5 \mathrm{mg} \Lambda \mathrm{BAP}+1 \mathrm{mg} / \mathrm{NAA}$ & + & White & $4.3 \pm 0.05$ & Friable \\
\hline $0.5 \mathrm{mg} / \mathrm{BAP}+0.5 \mathrm{mg} / 2,4-\mathrm{D}$ & $+1+$ & Green & $5.0 \pm 0.10$ & $"$ \\
\hline $0.5 \mathrm{mg} / \mathrm{BAP}+1 \mathrm{mg} / 2,4-\mathrm{D}$ & $+1+$ & Brownish & $4.2 \pm 0.09$ & $"$ \\
\hline $0.5 \mathrm{mg} / \mathrm{Kn}+0.5 \mathrm{mg} / \mathrm{NAA}$ & $+1+$ & Yellow green & $5.8 \pm 0.15$ & Compact \\
\hline $0.5 \mathrm{mg} / \mathrm{Kn}+1 \mathrm{mg} / \mathrm{NAA}$ & $+1+$ & Creamy & $3.7 \pm 0.07$ & Friable \\
\hline
\end{tabular}

\pm Standard error (SE).

In the present experiment callus derived from leaf explants were cultured on MS amended with two levels of sucrose ( 4 or $6 \%$ ) combined with two concentrations (0.1 and $0.5 \mathrm{mg} \Lambda$ ) of Kn for embryonic cultures development. Data of Table 3 showed that the higher embryonic callus frequencies (75 and $82 \%$ ) of the cultured callus were developed on sucrose $6 \%+\mathrm{Kn}(0.5 \mathrm{mg} \Lambda)$ containing medium after 4 and 8 weeks of sub-culturing respectively followed by sucrose $6+\mathrm{Kn}(0.1 \mathrm{mg} / \mathrm{l})$ containing medium (Table 3, Fig. 1). The results proved that there was a positive correlation between the high level of sucrose and development of embryonic culture of jojoba. In contrast, no embryonic callus was obtained in $4 \%$ sucrose and $0.1 \mathrm{mg} / \mathrm{Kn}$ containing medium. These data are consistant with the report from Tewfik and Noga 2002 as they found that the concentration of $\mathrm{Kn}$ with 2,4-D increased callus and followed embryonic stages of the callus in cumin. However, Gaber et al. (2007) reported that embryogenic callus and different stages of somatic embryos of jojoba were developed from leaf explants on MS $+2 \%$ sucrose, $1 \mathrm{mg} /$ 2,4-D and $0.25 \mathrm{mg} / \mathrm{BA}$. Whereas callus was developed from immature zygotic embryos on MS containing $1.0 \mathrm{mg} / 2$ 2, $\mathrm{D}, 0.1 \mathrm{mg} / \mathrm{BAP}$ and $4 \%$ sucrose (Hamama et al. 2001). 
Induced somatic embryos occurred where sub-cultured on MS supplemented with 4 or $6 \%$ sucrose and 0.1, 0.5 and $1.0 \mathrm{mM} \mathrm{Kn}$. In this respect, Zambre et al. (2002) mentioned that in most cases where embryogenesis occurred from callus, it turned green and this is considered a prerequisite for regeneration.

Lipid bodies are minute membrane-bound organelles that range in size from about 0.5 to $2.5 \mu \mathrm{m}$, which installed from the endoplasmic reticulum network. The effect of three doses $(5,10,15 \mathrm{Kr}$ ) of gamma radiation on oil bodies of embryonic cultures of jojoba (Fig. 2). The size of oil bodies slightly increased while the number of oil bodies remained the same size (Fig. 2, T2- e,f) compared to control sample (Fig. 2, T1 a, b, c) (see the white arrows). $\mathrm{T} 3$ treatment showed increased number of oil bodies in spite of decreasing their size (Fig. 2, T3-g,h,i). It is obvious that gamma radiation in $15 \mathrm{Kr}$ dose decreased the size and numbers of the oil bodies in the cells (Fig. $2, \mathrm{~T} 4-\mathrm{j}, \mathrm{k}, \mathrm{l})$. The T4 treatment showed no oil body at all. The results indicated that gamma ray up to $5 \mathrm{Kr}$ had a direct effect on the accumulation of triacylglycerols in cytosol to form oil bodies and the efficiency of endoplasmic reticulum to secrete it out to the cytosol.

Table 3. Embryonic callus of jojoba developed on medium contained different combinations of sucrose and Kn.

\begin{tabular}{lcc}
\hline Treatment & \multicolumn{2}{c}{ Embryonic callus (\%) } \\
\cline { 2 - 3 } & After four weeks & After eight weeks \\
\hline Sucrose $4 \%+\mathrm{Kn}(0.1 \mathrm{mg} /)$ & 0 & 0 \\
Sucrose $4 \%+\mathrm{Kn}(0.5 \mathrm{mg} / 1)$ & 25 & 36 \\
Sucrose $6 \%+\mathrm{Kn}(0.1 \mathrm{mg} / 1)$ & 55 & 65 \\
Sucrose $6 \%+\mathrm{Kn}(0.5 \mathrm{mg} / 1)$ & 75 & 82 \\
\hline
\end{tabular}

Total fixed oil data of embryonic cultures of jojoba wax related to the expose to different doses of gamma radiation (Table 4). Results revealed that the highest percentage of fixed oil (1.41) was produced from the treatment of $5 \mathrm{Kr}$. However, the lowest percentage (0.80) was registered with $15 \mathrm{Kr}$. It is clear that high doses (10 and 15 $\mathrm{Kr}$ ) of gamma radiation had negative effect on accumulation of fixed oil in cells of embryonic cultures of jojoba plant.

Table 4. Effect of gamma radiation doses of fixed oil of embryonic callus of jojoba.

\begin{tabular}{lc}
\hline Doses of gamma radiation & Fixed oil (\%) \\
\hline Without radiation (control) & 0.96 \\
$5 \mathrm{Kr}$ & 1.41 \\
$10 "$ & 0.85 \\
$15 "$ & 0.80 \\
\hline
\end{tabular}




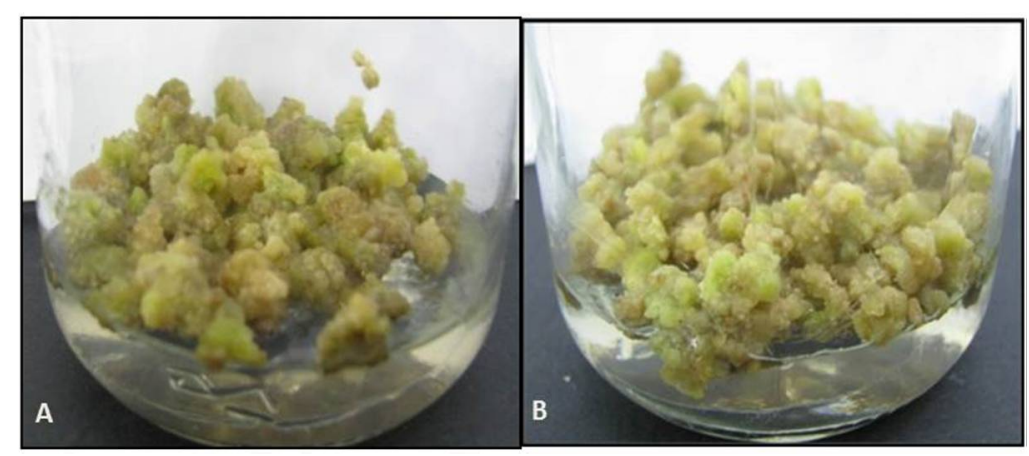

Fig. 1. Embryonic callus of jojoba developed on $6 \%$ sucrose $+\mathrm{Kn}(0.5 \mathrm{mg} /)$ containing medium after 4 (A) and 8 (B) weeks of sub-culturing.
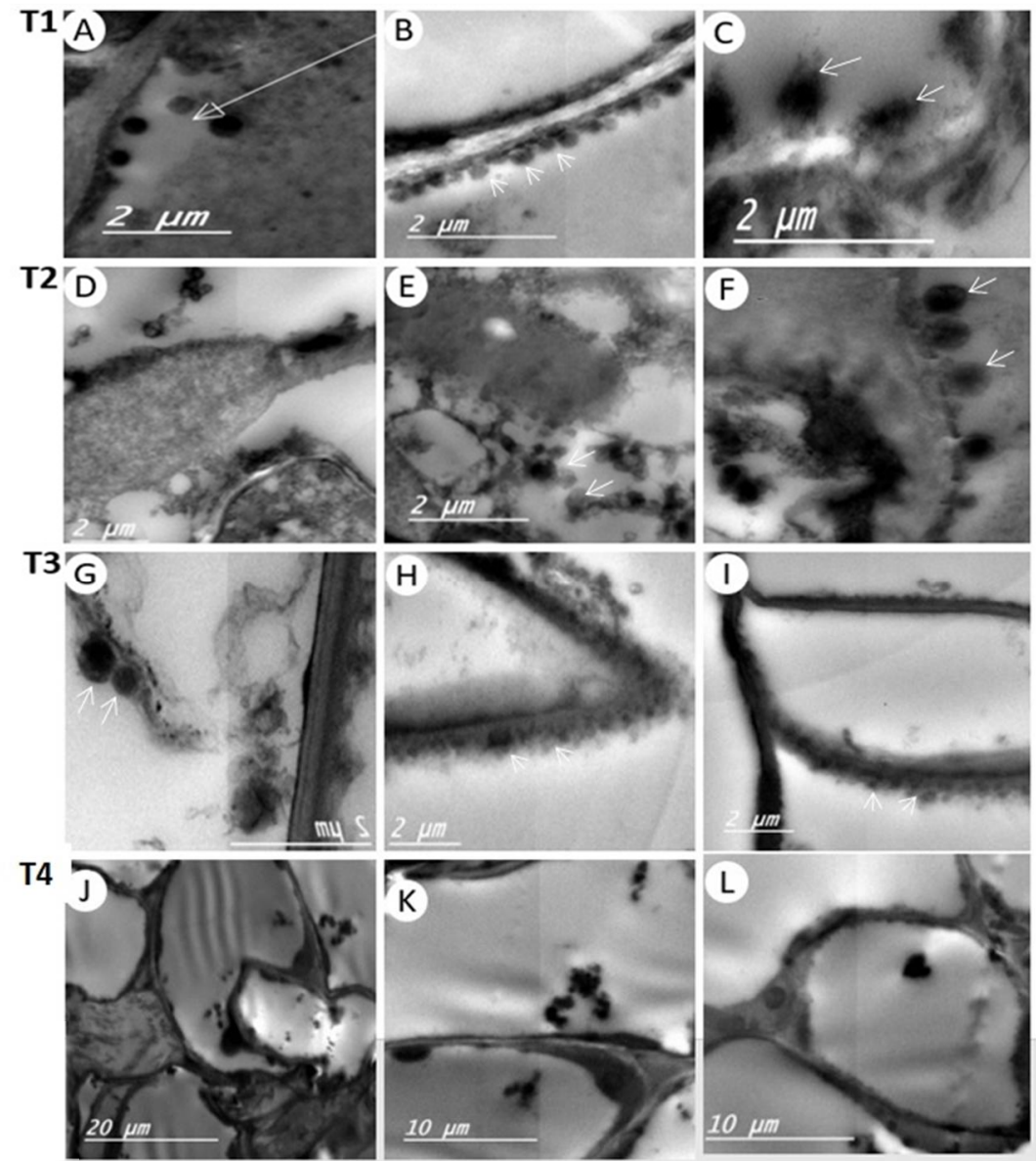

Fig. 2. The TEM image of oil bodies in mutagenesis embryonic cultures of jojoba exposed to gamma radiation. T1 $(\mathrm{A}, \mathrm{B}, \mathrm{C}), \mathrm{T} 2(\mathrm{D}, \mathrm{E}, \mathrm{F})$ emberyonic callus exposed to $5 \mathrm{Kr}, \mathrm{T} 3(\mathrm{G}, \mathrm{H}, \mathrm{I})$ emberyonic callus exposed to $10 \mathrm{Kr}$ and $\mathrm{T} 4(\mathrm{~J}, \mathrm{~K}, \mathrm{~L})$ emberyonic callus exposed to $15 \mathrm{Kr}$. The white arrows indicate the oil bodies size varience. 
Table 5. GLC analysis of fatty acids of embryonic callus of jojoba affected by gamma radiation.

\begin{tabular}{|c|c|c|c|c|c|c|c|}
\hline \multirow{2}{*}{$\begin{array}{l}\text { Peak } \\
\text { No. }\end{array}$} & \multirow[t]{2}{*}{ RT } & \multirow{2}{*}{$\begin{array}{l}\text { Carbon } \\
\text { No. }\end{array}$} & \multirow{2}{*}{$\begin{array}{l}\text { Common } \\
\text { name }\end{array}$} & \multicolumn{4}{|c|}{ Treatments } \\
\hline & & & & $\mathrm{T} 1$ & $\mathrm{~T} 2$ & T3 & $\mathrm{T} 4$ \\
\hline 1 & 8.421 & $\mathrm{C} 11: 0$ & Undecylic acid & - & 1.380 & - & - \\
\hline 2 & 9.637 & $\mathrm{C} 12: 0$ & Lauric acid & - & 3.112 & 5.104 & 4.707 \\
\hline 3 & 10.842 & C13: 0 & Tridecylic acid & - & 4.585 & 14.255 & 15.414 \\
\hline 4 & 11.909 & $\mathrm{C} 14: 0$ & Myristic acid & 0.457 & 3.540 & 16.126 & 12.922 \\
\hline 5 & 13.677 & $\mathrm{C} 15: 0$ & Pentadecylic acid & 1.257 & 0.859 & 3.471 & 2.386 \\
\hline 6 & 15.288 & $\mathrm{C} 16: 0$ & Palmitic acid & 44.239 & 17.605 & 12.148 & 15.820 \\
\hline 7 & 18.29 & $\mathrm{C} 18: 0$ & Stearic acid & 8.764 & 9.709 & 7.022 & 7.974 \\
\hline 8 & 18.69 & $\mathrm{C} 18: 1$ & Oleic acid & 28.822 & 31.311 & 25.275 & 28.755 \\
\hline 9 & 19.96 & $\mathrm{C} 18: 2$ & Linilic & 3.168 & 9.238 & 2.519 & 3.080 \\
\hline 10 & 21.40 & $\mathrm{C} 18: 3$ & Linolenic & 1.391 & 3.597 & 1.180 & 1.921 \\
\hline 11 & 22.332 & $\mathrm{C} 20: 0$ & Arachidic & 1.408 & 1.416 & - & 1.543 \\
\hline 12 & 23.827 & $\mathrm{C} 20: 1$ & Gadoleic & - & 1.034 & 1.175 & 0.857 \\
\hline 13 & 26.540 & $\mathrm{C} 22: 0$ & Behenic & - & 2.148 & 1.667 & 1.055 \\
\hline 14 & 28.930 & $\mathrm{C} 24: 0$ & Lignoceric & - & 1.178 & 3.481 & 1.583 \\
\hline 15 & 29.268 & $\mathrm{C} 24: 1$ & Nervonic acid & 1.143 & - & - & - \\
\hline 16 & 31.486 & $\mathrm{C} 26: 0$ & Cerotic acid & - & 3.150 & 5.189 & 3.574 \\
\hline \multicolumn{4}{|c|}{ Total fatty acids $\%$} & 90.649 & 93.742 & 98.612 & 98.059 \\
\hline \multicolumn{4}{|c|}{ Saturated fatty acids $\%$} & 55.525 & 47.146 & 68.463 & 63.446 \\
\hline \multicolumn{4}{|c|}{ Unsaturated fatty acids \% } & 35.124 & 46.596 & 30.149 & 34.613 \\
\hline
\end{tabular}

Without radiation (T1), cultures exposed to 5 (T2), 10 (T3) and $15 \mathrm{Kr}$ (T4).

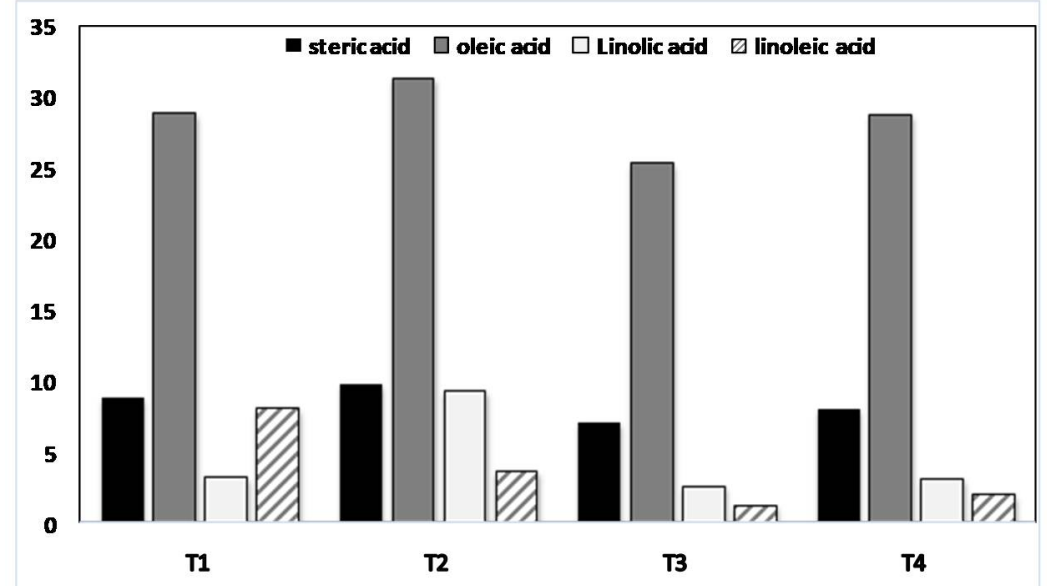

Fig. 3. GLC analysis of fatty acids methyl ester of embryonic cultures of jojoba exposed to different (0.0 - T1, 5 - T2, 10 - T3 and $15 \mathrm{Kr}$ - T4) gamma radiation. 
On the other hand, GLC analysis of methylated fatty acids of embryonic cultures treated by gamma radiation (Table 5, Fig. 3). Results indicated that main fatty acids of control treatment (without radiation) were palmitic acid (44.24), followed by oleic acid $(28.82 \%)$, then stearic acid $(8.76 \%)$ while linoleic acid reached $3.17 \%$. While, the treatment T2 $(5 \mathrm{Kr})$, the oleic acid was found as major compound and $(31.31 \%)$, followed by palmitic acid (17.61\%) then stearic acid and linoleic acid which gave relatively the same value (9.71 and $9.24 \%$ ), respectively. The main fatty acids were oleic acid (25.27 and $28.75 \%)$ and palimtic acid (12.15 and 15.82\%) followed by stearic acid (7.02 and 7.97\%) as well as linoleic acid which represented (2.52 and 3.08\%) for treatments T3 and T4 (10 and $15 \mathrm{Kr}$, respectively). It was noticed that $\mathrm{T} 3$ and $\mathrm{T} 4$ (10 and $15 \mathrm{Kr}$ ) enhanced the accumulation of tridecylic acid (14.25 and 15.41\%) and myristic acid (16.13 and 12.92\%) as compared to T2 ( $5 \mathrm{Kr}$ ) and control treatment which gave the lowest values (4.59 and $3.54 \%$, respectively). On other side, the total saturated fatty acids constituted $68.46 \%$ for T3 $(10 \mathrm{Kr})$ followed by $63.45 \%$ for $\mathrm{T} 4(15 \mathrm{Kr})$, then $55.53 \%$ for $\mathrm{T} 1$ (without radiation). From the results it can be recommended that the highest values of both percentages of fixed oil and unsaturated fatty acids as well as oleic acid (C18:2) was roistered when embryonic cultures were treated with $5 \mathrm{Kr}$ of gamma radiation. However, this treatment gave low values for both tridecylic and myristic acid as compared to T3 $(10 \mathrm{Kr})$ and T4 $(15 \mathrm{Kr})$. Moreover, the compounds of tridecylic and myristic acids were absent in the control treatment.

Gamma rays are known to influence plant growth and development by inducing cytological, genetic, biochemical, physiological and morphogenetic changes in cells and tissue (Gunckel and Sparrow 1961). In the present study, the size of oil bodies of radiated embryonic callus of jojoba was increased compared to control especially with dose of 5 $\mathrm{Kr}$ of gamma radiation. Also, the fatty acids of embryonic callus of jojoba were enhanced by treating with different doses of gamma radiation. The highest percentage of fixed oil was registered with $5 \mathrm{Kr}$. However, the highest content of total fatty acids was obtained when embryonic calluses were exposed to $10 \mathrm{Kr}$ of gamma radiation. Present results are supported by previous studies that reported increased oil production subsequent to gamma irradiation in several plant species (Sattar et al. 1989). In this respect, Dehpour (1998) mentioned that different doses of gamma radiation increased protein content and chemical and physical properties of oil seeds such as increasing of iodine value, free fatty acid of soybean. Likewise, gamma irradiation at 20 Gy enhanced positively total phenolic and flavonoid accumulation in rosemary callus culture (El-Beltagi et al. 2011). The present results are also in conformity with Aftab et al. 2008. They mentioned that quantitative estimation of oils of different explants of jojoba revealed that cotyledonary explants contained highest amount of oil. In this respect, manipulating growth regulators in the somatic embryo induction media influences the quality and quantity of fatty acids. Aly et al. (2008) indicated that palmitic acid, stearic acid, oleic acid, linoleic acid and linolenic acid are significantly higher in immature than mature seeds. In their study on induction of biochemical active constituents in callus of jojoba, Solliman et al. (2017) mentioned that 
increased Kn concentration led to slightly double the increase in active constituents from the explants for triodecanoic and methoxyacetic acids. While, the gradual increase of 2,4$\mathrm{D}$ to $2.0 \mathrm{mg} /$ caused increase in active constituents for triodecanoic, methoxyacetic and octadecanoic acid, respectively.

\section{References}

Aftab F, Akram F and Iqbal J (2008) Estimation of fixed oils from various explants and in vitrocallus culture of jojoba (Simmondsia chinensis). Pak. J. Bot. 40: 1467-1471.

Aly MA, Amer EA, Al-Zayadneh WA and Eldin AEN (2008) Growth regulators influence the fatty acid profiles of in vitro induced jojoba somatic embryos. Plant Cell, Tissue and Organ Culture 93: 107-114.

AOAC (1995) Official Methods of Análysis of the Association of Official Analytical Chemist International. Vol. I 16th edition. Maryland, U.S.A.

Bala R, Beniwal VS and Laura JS (2015) An efficient and reproducible indirect shoot regeneration from female leaf explants of Simmondsia chinensis, a liquid-wax producing shrub. Physiol. Mol. Biol. Plants 21(2): 293-299.

Benzioni A (1995) Jojoba domestication and commercialization in Israel. Hortic. Rev. 17: 234-266.

Bhardwaj M, Uppal S, Jain S, Kharb P, Dhillon R and Jain RK (2010) Comparative assessment of ISSR and RAPD marker assays for genetic diversity analysis in jojoba (Simmondsia chinensis (Link) Schneider). J. Plant Biochem. Biotechnol. 19: 255-258.

Birnbaum E, Matias S and Wenkart S (1984) Vegetative propagation of jojoba by tissue culture. In: Wisniak J, Zabicky J (eds)Proceedings of the sixth international conference on jojoba and its uses. Ben Gurion University, Beer-Sheva, pp. 233-241.

Chaturvedi HC and Sharma M (1989) In vitro production of cloned plants of jojoba (Simmondsia chinensis (Link) Schneider) through shoot proliferation in long term culture. Plant Sci. 63: 199-207.

Dehpour AA (1998) Effect of gamma irradiation on some biochemical parameters and physicochemical properties of oil in soybean [Glycine max (L.) Merr.]. Iranian Journal of Plant Physiology 7(2): 1991-1998.

El-Ashry AA, Gabr AMM and Bekheet SA (2017) Zeatin and thidiazuron induced embryogenic calli from in vitro leaf and stem of jojoba (Simmondsia chinensis). Pak. J. Biol. Sci. 20(7): 355364.

El-Beltagi HS, Ahmed OK and El-Desouky W (2011) Effect of low doses $\gamma$-irradiation on oxidative stress and secondary metabolites production of rosemary (Rosmarinus officinalis L.) callus culture. Radiation Physics and Chem. 80(9): 968-976.

Gaber A, El-Maraghy HMM, Aly MAM, Rashed NAK and El-Din GAY (2007) Induction of somatic embryogenesis and DNA fingerprinting of jojoba, Arab J. Biotech. 10(2): 341-354.

Gunckel JE and Sparrow AH (1961) Ionizing radiations: Biochemical, physiological and morphological aspects of their effects of plants. Encyclopedia of Plant Physiology, SpringerVerlag, Berlin 16: 555-611.

Hamama L, Baaziz M and Letouze R (2001) Somatic embryogenesis and plant regeneration from leaf tissue of jojoba. Plant Cell Tissue Organ Cult. 65: 109-113.

Ibrahim AS, El Shihy OA and Hamdy BM (2018) An Improved regeneration protocol of female jojoba (Simmondsia chinensis) plants from callus derived from leaf explants. J. Horticultural Science \& Ornamental Plants 10(2): 81-90. 
Improvement of Wax Oil Content of Embryonic Callus

Kim SW and Liu JR (1999) Somatic embryogenesis and plant regeneration in zygotic embryo cultures of balloon flower. Plant Cell Tiss. Org. Cult. 58: 227-230.

Kovacs E and Keresztes A (2002) Effect of gamma and UV-B/C radiation on plant cell. Micron 33: 199-210.

Kumar S, Mangal M, Dhawan AK and Singh N (2013) Callus induction and plant regeneration from leaf explants of jojoba (Simmondsia chinensis (Link) Schneider). Indian J. Biotechnology 12: 544-547.

Lee CW (1988) Application of plant biotechnology for clonal propagation and yield enhancement in jojoba. In: Baldwin AR (ed). Proceeding of the Seventh International Conference on Jojoba and its Uses. Illinois, USA, pp 102-111.

Lee CW and Thomas JC(1985) Jojoba embryo culture and oil production. Hort. Sci. 20: 762-764.

Low CBandHackett WP (1981) Vegetative propagation of jojoba. Calif. Agric. 35: 12-13.

Maestri DM and Guzmán CA (1995) A comparative study of seed lipid components of Nicotianeae (Solanaceae): Biochem. Syst. Ecol. 23: 201-207.

Mills D, Wenkart S and Benzioni A (1997) Micropropagation of Simmondsia chinensis (Jojoba). In: Bajaj YPS (ed) Biotechnology in Agriculture and Forestry, Vol. 40. High-tech and micropropagation VI. Springer, Berlin, pp. 370393.

Reddy MP and Chikara J (2010) Biotechnology advances in jojoba (Simmondsia chinensis). In: Ramawat KG (ed) Desert plants. Springer, Berlin, pp. 407-422.

Rost TL and Paterson KE (1978) Structural and histochemical characterization of the cotyledon storage organelles of jojoba (Simmondsia chinensis). Protoplasma 95: 1-10.

Sardana J andBatra A (1998) In vitro regeneration of jojoba (Simmondsia chinensis) a plant of high potential. Adv. Plant Sci. 11: 143-146.

Sattar A, Ahmad M, Hussain A and Khan I (1989) Light induced oxidation of nut oils. Die Nahrung 33: 213-215.

Snedecor GW and Cochran WG (1980) Statistical Methods, Seventh Edition, Ames: Iowa State University Press.

Solliman M, Shehata WF, Mohasseb HAA, Aldaej MI, Al-Khateeb AA, Al-Khateeb SA, Hegazy AEA and Abdel-Moneim HM (2017) Induction of biochemical active constituents of Jojoba (Simmondsia chinensis (Link). Schneider) callus affected by hormones. Journal of Medicinal Plants Research 11(2): 34-42.

Tawfik AA and Noga G (2002) Cumin regeneration from seedling derived embryogenic callus in response to amended kinetin. Plant Cell Tiss. Org. Cult. 69: 35-40.

Wang YC and Janick J (1986a) Somatic embryogenesis in jojoba. J. Am. Soc. Hortic. Sci. 111: 281287.

Wang YC and Janick J (1986b) In vitro production of jojoba liquid wax by zygotic and somatic embryos. J. Am. Soc. Hortic. Sci. 111: 798-806.

Wi SG, Chung BY, Kim JH, Baek MH, Yang DH, Lee JW and Kim JS (2005) Ultra structural changes of cell organelles in Arabidopsis stem after gamma irradiation. J. Plant Biol. 48: 195200.

Zambre M, Chowdhury B, Kuo YH, Montagu MV and Angenon G (2002) Prolific regeneration of fertile plants from green nodular callus induced from meristematic tissues in Lathyrus sativus L. (Grass pea). Plant Sci. 163:117-1112. 